\title{
Role of Complexed PSA in the Early Detection of Prostate Cancer
}

\author{
Yoshio Naya, MD, PhD,* and Koji Okihara, MD, PhD, ' Osaka and Kyoto, Japan
}

\section{Key Words}

$\overline{\text { Prostate, prostatic neoplasm, detection, prostate-specific antigen, }}$ complexed PSA

\begin{abstract}
Prostate cancer is a clinically significant health care problem in the United States. Total prostate specific antigen (tPSA) is widely used to detect prostate cancer with a significant increase in the incidence of organ-confined disease at the time of diagnosis. The limitations of tPSA are low specificity and positive predictive value. Numerous attempts to enhance PSA's performance based on prostate volume, patient age, patient race, and PSA velocity have shown little clinical improvement. Percent free PSA has proven to be somewhat improved but still limited. Recently, the complexed PSA (CPSA) assay was developed and multisite institutional studies have shown that CPSA has improved specificity over tPSA. Complexed PSA can replace tPSA as a first screening test. (JNCCN 2004;2:209-212).
\end{abstract}

Early detection of prostate cancer is an important health care problem. The prostate-specific antigen (PSA) assay is widely used for the detection of prostate cancer. ${ }^{1,2}$ However, the diagnostic value of total PSA (tPSA) for detection of prostate cancer is limited by its lack of specificity. PSA is neither organ specific nor tumor specific. ${ }^{3}$ Elevations in PSA may be caused by benign prostatic hyperplasia $(\mathrm{BPH})$, prostatic inflammation, ejaculation, and urologic manipulations as well as by prostate cancer. ${ }^{4}$ To improve the specificity of tPSA for detecting prostate cancer, various enhancements have been developed, such

From the *Department of Urology, Matsushita Memorial Hospital, Osaka, and the Department of Urology, Kyoto Prefectural University of Medicine, Kyoto, Japan.

Received January 6, 2004; accepted for publication February 19, 2004.

The authors have no financial interests, arrangement, or affiliations with the manufacturers of any products discussed in the article or with their competitors.

Correspondence: Yoshio Naya, MD, PhD, Department of Urology, Kyoto Prefectural University of Medicine, Kawaramachi-Hirokoji, Kyoto, Japan, 602-8566. E-mail: yoshionaya@hotmail.com as tPSA density (PSAD), PSAD of transition zone (PSAD-TZ), age- and race-referenced PSA, volume-referenced PSA, or percent free PSA (fPSA). ${ }^{3,5-8}$ In men with tPSA between 4.1 and $10.0 \mathrm{ng} / \mathrm{mL}$, the $25 \% \mathrm{fPSA}$ cutoff has been reported to decrease the number of unnecessary biopsies by $20 \%$, while maintaining $95 \%$ sensitivity. ${ }^{8}$ Another study suggested that percent fPSA can enhance specificity for detecting prostate cancer in men with tPSA between 2.5 and $4.0 \mathrm{ng} / \mathrm{mL} .{ }^{9}$ However, the clinical effectiveness of the free-to-total PSA ratio is reduced in men with tPSA values between 2.5 and 4.0 $\mathrm{ng} / \mathrm{mL} \cdot{ }^{10-12}$

Complexed PSA (cPSA) is an alternative approach to PSA testing. Serum PSA exists primarily as either the free "non-complexed form" or as a complex predominantly with alpha 2 -macrogrobulin and alpha 1 -antichymotrypsin (ACT), and to a lesser degree with

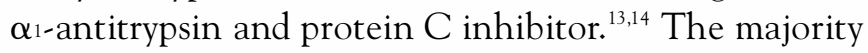
of PSA present in serum is complexed to protease inhibitors with a higher percentage of PSA bound to ACT in men with malignancy compared with benign disease. ${ }^{14,15}$ The cPSA assay measures PSA-ACT and other immunoreactive-bound PSA forms, such as PSA- $\alpha_{1}$-protease inhibitor. ${ }^{16}$ Several studies have shown that cPSA enhances the specificity over tPSA greater than $4 \mathrm{ng} / \mathrm{mL}$ or tPSA between 2.6 to $20 \mathrm{ng} / \mathrm{mL} .^{17-19}$ This article reviews the evidence for the current and future roles of cPSA for early prostate cancer detection.

\section{cPSA Assay}

The basic cPSA assay became available in 1998 as Bayer Immuno 1 PSA and cPSA immunoassays (Bayer Diagnostics, Tarrytown, NY). The Bayer PSA assay uses a monoclonal antibody for its capture phase, and affinity-purified goat polyclonal antibodies linked to alkaline phosphatase for its detection of fPSA and cPSA based 
on the properties of the monoclonal antibody used for capture. ${ }^{18,20}$ Moreover, the Bayer Immuno 1 cPSA test contains a separate unlabeled antibody specific for fPSA, along with the antibodies used for the detection and capture of tPSA. The additional antibody is used to render fPSA immunologically nonreactive. ${ }^{16,18}$

Recently, the Bayer ADVIA-Centaur cPSA assay (Bayer Medical Limited, Tokyo, Japan) was developed from the Bayer Immuno 1 cPSA assay. ${ }^{21}$ Basically, the Centaur cPSA assay uses the same measuring method theory as the Immuno $1 \mathrm{cPSA}$ assay. In the Immuno 1 assay, however, fPSA is prevented from reacting with the tPSA antibodies by incubating the sample with an fPSA-specific monoclonal mouse antibody, and the cPSA antibody conjugate was labeled with alkaline phosphatase. In contrast, a light reagent with polyclonal goat anti-PSA antibody with an acridinium eater is applied in Centaur assay. ${ }^{22}$ These differences between Immuno 1 and Centaur assay led to a continuous operation and cost-effective workstation consolidation in the Centaur assay. The minimum detection sensitivity of Immuno $1 \mathrm{cPSA}$ is $0.2 \mathrm{ng} / \mathrm{mL}$ and that of Centaur cPSA is $0.03 \mathrm{ng} / \mathrm{mL}$. Moreover, sample throughput in the Centaur cPSA and Immuno 1 assays can perform 240 tests/h and 100 tests/h, respectively.

\section{Clinical Trials for Early Prostate Cancer Detection}

Several reports have suggested that cPSA could be a better initial test for prostate cancer detection than tPSA. Brawer et al. ${ }^{17}$ published the first report showing that cPSA improved the specificity over tPSA and free-tototal PSA ratio. At tPSA ranges of 4.0 to $10.0 \mathrm{ng} / \mathrm{mL}$, the authors reported that, at high sensitivity, cPSA enhanced specificity over tPSA. Similarly, Okegawa et al ${ }^{23}$ reported that free-to-complexed PSA ratio (f/cPSA) enhanced the specificity at high sensitivity among 140 biopsy-confirmed Japanese men whose tPSA level was between 4.0 and $10.0 \mathrm{ng} / \mathrm{mL}$. Stamey and Yemoto, ${ }^{24}$ however, showed equivalent or modest improvement in specificity for cPSA relative to tPSA.

In a retrospective multisite institutional study (Brigham and Women's Hospital, The Johns Hopkins Hospital, Memorial Sloan Kettering Cancer Center, the Northwest Prostate Institute and University of Washington, and The University of Texas M. D. Anderson Cancer Center), Okihara et al. ${ }^{25}$ reported that cPSA and complexed-to-total PSA ratio (per- cent cPSA) is equivalent to tPSA for the early detection of prostate cancer. They also reported that percent fPSA outperformed cPSA and percent cPSA performed equivalently to percent fPSA in men with tPSA levels between 2.5 and $10.0 \mathrm{ng} / \mathrm{mL}$.

With tPSA levels between 2.5 and $4.0 \mathrm{ng} / \mathrm{mL}$, a significant number of men will have prostate cancer. ${ }^{26,27}$ Previous studies ${ }^{26-28}$ have shown that of the men whose tPSA is between 2.5 and $4.0 \mathrm{ng} / \mathrm{mL}$, approximately $22 \%$ to $27 \%$ will be diagnosed with prostate cancer. Approximately $80 \%$ of the patients in this PSA range who underwent radical prostatectomy had clinically significant cancer and were potentially curable. ${ }^{26}$

Okihara et al. ${ }^{29}$ reported that cPSA was more specific than $\mathrm{f} / \mathrm{tPSA}$ when tPSA was between 2.5 and 4.0 $\mathrm{ng} / \mathrm{mL}$. Receiver operating characteristic (ROC) analysis showed that cPSA (area-under-the-curve [AUC] = 0.718 ) had a better performance compared with percent fPSA (AUC $=0.635)$. They concluded that a 2.2 $\mathrm{ng} / \mathrm{mL}$ cutoff for cPSA appeared to stratify prostate biopsy results in men with tPSA between 2.5 and 4.0 $\mathrm{ng} / \mathrm{mL}$. They also reported that cPSAD and cPSADTZ had the best specificities compared with percent fPSA and non-volume-referenced cPSA. They found that volume-referenced cPSA might enhance detection specificity in larger prostates ( $30 \mathrm{~mL}$ or greater).

A recently conducted, 7-site institutional study (Johns Hopkins Medical Institution, New York University, Northwest Prostate Institute, Stanford University, University of Innsbruck, University of Texas M. D. Anderson Cancer Center, and Wyoming Research Foundation) examined several studies. Horninger et al. ${ }^{30}$ reported that the use of cPSA as a single test enhanced the detection of prostate cancer over that of testing with tPSA and tPSA indices in men with tPSA values between 2 and $4 \mathrm{ng} / \mathrm{mL}$. Naya et al. ${ }^{31}$ reported that cPSA, cPSAD, and cPSAD-TZ enhanced cancer detection in men with tPSA between 2.5 and $10.0 \mathrm{ng} / \mathrm{mL}$, especially when the tPSA was between 2.5 and $4.0 \mathrm{ng} / \mathrm{mL}$. They compared the ultrasound-estimated prostate volume with that of the prostate weight obtained from radical prostatectomy and found the importance of the accurate measurement of the total prostate volume and transition zone volume. They also concluded that $2.2 \mathrm{ng} / \mathrm{mL}$ for cPSA was the cutoff value differentiating cancer from benign disease in the tPSA range of 2.5 to $4.0 \mathrm{ng} / \mathrm{mL}$.

Partin et al. ${ }^{32}$ reported that the use of cPSA as a single test provided improved specificity over tPSA. Percent 
fPSA and percent cPSA offered little to no additional benefit in differentiating benign from malignant disease at clinically relevant cPSA concentrations. Within the cPSA range of 3.2 to $8.3 \mathrm{ng} / \mathrm{mL}$ (4-10 ng/mL tPSA range), the percent fPSA and percent cPSA provided a significant improvement in AUC over tPSA and cPSA. However, no differences were seen with AUC results for percent fPSA or percent cPSA across all cPSA ranges.

The European multisite institutional study of Djavan et al. ${ }^{33}$ showed that the performance of cPSA was better than tPSA in differentiation between benign disease and prostate cancer, and similar to that of percent fPSA in men with tPSA levels between 4 and $10 \mathrm{ng} / \mathrm{mL}$. They also reported that cPSAD and cPSAD-TZ further improved the specificity of PSA in early detection of prostate cancer.

A recent preliminary study from Japan showed that the novel Bayer cPSA (Centaur assay) could enhance prostate cancer detection in Japanese men compared with tPSA and PSA-ACT. ${ }^{21}$ This report showed that cPSA is promising in differentiating malignancy from benign disease in men with a tPSA value less than 4.0 $\mathrm{ng} / \mathrm{mL}$.

\section{Conclusions}

We reviewed the role of cPSA for early detection of prostate cancer. Using a $2.2 \mathrm{ng} / \mathrm{mL}$ cutoff for cPSA enhances prostate cancer detection compared with percent fPSA in the tPSA range of 2.5 to $4.0 \mathrm{ng} / \mathrm{mL}$. Volume-referenced cPSA, such as cPSAD and cPSAD-TZ, appears to enhance prostate cancer detection compared with percent fPSA and percent cPSA. Complexed PSA is measured by one test and the free-to-total PSA ratio requires 2 tests. Therefore, the use of percent fPSA in men with tPSA levels greater than $4 \mathrm{ng} / \mathrm{mL}$ clearly increases the assay cost as well as introduces the problems associated with laboratory and biologic variability. Complexed PSA is a better initial test than tPSA for early cancer detection.

\section{References}

1. Jemal A, Murray T, Samuels A, et al. Cancer statistics, 2003. CA Cancer J Clin 2003;53:5-26.

2. Catalona WJ, Smith DS, Ratliff TL, et al. Measurement of prostate-specific antigen in serum as a screening test for prostate cancer. N Engl J Med 1991;324:1156-1161.

3. Babaian RJ, Kojima M, Ramirez EI, et al. Comparative analysis of prostate specific antigen and its indexes in the detection of prostate cancer. J Urol 1996;156:432-437.
4. Nalder RB, Humphrey PA, Smith DS, et al. Effect of inflammation and benign prostatic hyperplasia on elevated serum prostatic specific antigen levels. J Urol 1995;154:407-413.

5. Djavan B, Zlotta AR, Byttebier G, et al. Prostate specific antigen density of the transition zone for early detection of prostate cancer. J Urol 1998;160:411-418.

6. Maeda H, Arai Y, Ishitoya S, et al. Prostate specific antigen adjusted for the transition zone volume as an indicator of prostate cancer. J Urol 1997;158:2193-2196.

7. DeAntoni EP, Crawford ED, Oesterling JE, et al. Age- and race-specificreference ranges for prostate-specificantigen from a large community-based study. Urology 1996;48:234-239.

8. Catalona WJ, Partin AW, Slawin KM, et al. Use of the percentage of free prostate-specific antigen to enhance differentiation of prostate cancer from benign prostatic disease. A prospective multicenter clinical trial. JAMA 1998; 279:1542-1547.

9. Catalona WJ, Partin AW, Finlay JA, et al. Use of percentage of free prostate-specificantigen to identify men at high risk of prostate cancer when PSA levels are 2.51 to $4 \mathrm{ng} / \mathrm{ml}$ and digital rectal examination is not suspicious for prostate cancer: an alternative model. Urology 1999;54:220-224.

10. Djavan B, Zlotta A, Kratzik C, et al. PSA, PSA density, PSA density of transition zone, free/total PSA ratio, and PSA velocity for early detection of prostate cancer in men with serum PSA 2.5 to $4.0 \mathrm{ng} / \mathrm{mL}$. Urology 1999;54:517-522.

11. Jung K, Stephan C, Elgeti U, et al. Molecular forms of prostate-specificantigen in serum with concentrations of total prostate-specific antigen $<4 \mu \mathrm{g} / \mathrm{L}$ : Are they useful tools for early detection and screening of prostate cancer? Int J Cancer 2001;93:759-765.

12. Roehl KA, Antenor JV, Catalona WJ. Robustness of free prostate specific antigen measurements to reduce unnecessary biopsies in the 2.6 to $4.0 \mathrm{ng} / \mathrm{mL}$ range. J Urol 2002;168:922-925.

13. Stenman UH, Leinonen J, Alfthan $H$, et al. A complex between prostate-specificantigen and alpha 1-antichymotrypsin is the major form of prostate-specificantigen in serum of men with prostatic cancer: Assay of the complex improves clinical sensitivity for cancer. Cancer Res 1991;51:222-226.

14. Christensson $A$, Bjork $T, N$ ilsson $O$, et al. Serum prostate specific antigen complexed to alpha 1-antichymotrypsin as an indicator of prostate cancer. J Urol 1993;150:100-105.

15. Lilja H, Christensson A, Dahlen U, et al. Prostate specific antigen (PSA) in human serum occurs predominantly in

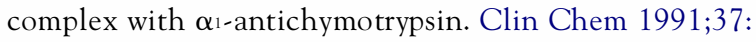
$1618-1625$.

16. Allard WJ, Zhou Z, Yeung KK, et al. Novel immunoassay for the measurement of complexed prostate-specificantigen in serum. Clin Chem 1998;44:1216-1223.

17. Brawer MK, Meyer GE, Letran JL, et al. Measurement of complexed PSA improves specificity for early detection of prostate cancer. Urology 1998;52:372-378.

18. Brawer MK, Meyer GE, Letran JL, et al. Complexed prostate specific antigen provides significant enhancement 
of specificity compared with total prostate specific antigen for detecting prostate cancer. J Urol 2000;163:1476-1480.

19. Mitchell ID, Croal BL, Dickie A, et al. A prospective study to evaluate the role of complexed prostate specific antigen ratio for the diagnosis of prostate cancer. J Urol 2001; 165:1549-1553.

20. Morris DL, Dillon PW, Very DL, et al. Bayer Immuno 1 PSA Assay: an automated, ultrasensitive method to quantitate total PSA in serum. J Clin Lab Anal 1998;12:65-74.

21. Okihara K, Ukimura $O$, Nakamura $T$, et al. Can complexed prostate specific antigen enhance prostate cancer detection in Japanese men? Eur Urol (in press).

22. Ian W, Iraj B, Frank M, et al. Acridinium esters as highspecific-activitylabels in immunoassay. Clin Chem 1983;29: 1474-1479.

23. Okegawa T, Noda H, Nutahara K, et al. Comparison of two investigative assays for the complexed prostate specificantigen in total prostate-specific antigen between 4.1 and $10.0 \mathrm{ng} / \mathrm{mL}$. Urology 2000;55:700-704.

24. Stamey TA, Yemoto CE. Examination of the 3 molecular forms of serum prostate specific antigen for distinguishing negative from positive biopsy: relationship to transition zone volume. J Urol 2000;163:119-126.

25. Okihara K, Cheli CD, Partin AW, et al. Comparative analysis of complexed prostate specific antigen, free prostate specific antigen and their ratio in detecting prostate cancer. J Urol 2002;167:2017-2024.

26. Catalona WJ, Smith DS, Ornstein DK. Prostate cancer detection in men with serum PSA concentrations of 2.6 to $4.0 \mathrm{ng} / \mathrm{ml}$ and benign prostate examination. Enhancement of specificity with free PSA measurements. JAMA 1997;277:1452-1455.
27. Smith DS, Carvalhal GF, Mager DE, et al. Use of lower prostate specific antigen cutoffs for prostate cancer screening in black and white men. J Urol 1998;160:1734-1738.

28. Babaian RJ, Johnston DA, Naccarato W, et al. The incidence of prostate cancer in screening population with a serum prostate specific antigen between 2.5 and $4.0 \mathrm{ng} / \mathrm{ml}$ : relation to biopsy strategy. J Urol 2001;165:757-760.

29. Okihara K, Fristche HA, Ayala A, et al. Can complexed prostate specific antigen and prostatic volume enhance prostate cancer detection in men with total prostate specific antigen between 2.5 and $4.0 \mathrm{ng} / \mathrm{ml}$. J Urol 2001;165: 1930-1936.

30. Horninger W, Cheli CD, Babaian RJ, et al. Complexed prostate-specificantigen for early detection of prostate cancer in men with serum prostate-specific antigen levels of 2 to 4 nanograms per milliliter. Urology 2002;60(Suppl $4 a): 31-35$

31. Naya Y, Stamey TA, Cheli CD, et al. Can volume measurement of the prostate enhance the performance of complexed prostate-specificantigen? Urology 2002;60(Supp14a):36-41.

32. Partin AW, Brawer MK, Bartch G, et al. Complexed prostate specific antigen improves specificity for prostate cancer detection: results of a prospective multicenter clinical trial. J Urol 2003;170:1787-1791.

33. Djavan B, Remzi M, Zlotta AR, et al. Complexed prostatespecific antigen, complexed prostate-specific antigen density of total and transition zone, complexed/total prostatespecific antigen ratio, free-to-total prostate-specificantigen ratio, density of total and transition zone prostate-specific antigen: results of the prospective multicenter European trial. Urology 2002;60(Suppl 4a):4-9. 